\title{
The Impact of Microfinance on Household Welfare in Rural Vietnam : A Case Study in Phu Tho Province
}

DANG, Thi Hai Yen

Laboratory of Agricultural and Farm Management, Department of Agricultural and Resource Economics, Graduate School of Bioresource and Bioenvironmental Sciences, Faculty of Agriculture, Kyushu University |Laboratory of Agricultural and Farm Management, Department of Agricultural and Resource Economics, Faculty of Agriculture, Kyushu University

\section{NANSEKI, Teruaki}

Laboratory of Agricultural and Farm Management, Department of Agricultural and Resource Economics, Graduate School of Bioresource and Bioenvironmental Sciences, Faculty of Agriculture, Kyushu University

\section{CHOMEI, Yosuke}

Laboratory of Agricultural and Farm Management, Department of Agricultural and Resource Economics, Graduate School of Bioresource and Bioenvironmental Sciences, Faculty of Agriculture, Kyushu University

https://doi.org/10.5109/1911234

出版情報：九州大学大学院農学研究院紀要.63 (1)，pp. 185-189，2018-02-27. Faculty of Agriculture, Kyushu University バージョン：

権利関係 : 


\title{
The Impact of Microfinance on Household Welfare in Rural Vietnam: A Case Study in Phu Tho Province
}

\author{
Thi Hai Yen DANG ${ }^{1,2}$, Teruaki NANSEKI ${ }^{1 *}$ and Yosuke CHOMEI ${ }^{1}$ \\ Laboratory of Agricultural and Farm Management, Department of Agricultural and Resource Economics, \\ Faculty of Agriculture, Kyushu University, Fukuoka 812-8581, Japan \\ (Received October 31, 2017 and accepted November 20, 2017)
}

\begin{abstract}
In Vietnam, microfinance is regarded as one of the important measures to reduce poverty. However, empirical findings indicated that microfinance services can only meet less than half of the poor's demand. About 3.6 poor and near poor households remained vulnerable to external shocks in 2012. Therefore, this study aims to examine whether and to what extent microfinance programs have helped to increase household economic welfare in rural Vietnam. A survey was conducted in Phu Tho province - one of the poorest areas in the northern of Vietnam through face-to-face structured interviews with 257 respondents. The study employs a two stage least square regression model to deal with self-selection bias in the evaluation of the impact of microfinance on household welfare. The main outcome indicates that formal microfinance has helped to increase the household economic welfare in terms of per capita income, expenditure and value of non-land asset of the household with the coefficients are 0.002, 0.004, 0.003, respectively. Although the effect is small, microfinance has helped the better-off groups to increase their income and expenditure, while the poor groups increase their expenditure and acquire more assets, implying that the credit is distributed to other purpose besides income generating. However, these small impacts suggest a further study about the cost-effective of the microfinance programs.
\end{abstract}

Key words: Microfinance, Poverty Alleviation, Household Welfare, Two Stage Least Square Model (2SLS)

\section{INTRODUCTION}

Regarding to World Bank 2011, Vietnam is a developing country with low-income, which 72 percent of its population live in rural areas. Agriculture remains the key economic sector, account for 54 percent of the labor force. Vietnam has significantly reduced its poverty incidence from 58\% in 1993 to only 10\% in 2013. During this period, the percentage of rural population having access to credit increased significantly from 23\% to $40 \%$ (GSO - Vietnam General Statistics Office). Therefore, Microfinance has been recognized as an important instrument to fight again poverty (Nguyen, Ngo, Le and Nguyen, 2011). Due to the Vietnamese Government supported policy, Vietnam has 52 microfinance institutions, serving about 12.3 million clients or 14 percent of the country's population (Nguyen et al., 2011). However, only about $11 \%$ of the poorest $40 \%$ of the population in Vietnam has an account in a formal financial institution (World Bank, 2011). In addition, the Vietnam Ministry of Labor reported that 2.1 million poor households and 1.5 million near poor households remain vulnerable to external shocks in 2012. Poverty incidence has been disproportionately higher in rural areas and among ethnic minorities. Hence, it is important to assess the impact of microfinance programs on household welfare to ensure that microfinance resources have been delivered effi-

\footnotetext{
1 Laboratory of Agricultural and Farm Management, Department of Agricultural and Resource Economics, Graduate School of Bioresource and Bioenvironmental Sciences, Faculty of Agriculture, Kyushu University

2 Department of Finance, Faculty of Accounting and Business Management, Vietnam University of Agriculture

* Corresponding author: nanseki@agr.kyushu-u-ac.jp
}

ciently to their purpose of poverty alleviation.

Over the last few decades, many researchers have attempted to examine microfinance role to household welfare. However, the available empirical studies have found a controversy and inconclusiveness. One group of authors suggested that microfinance has a significant and positive contribution to poverty reduction such as Pitt and Khandker (1988), Khandker and Faruquee (2003), and Quach, Mullineux, and Murinde (2007). The opposite group argued that there is negligible impact of microfinance, such as Nghiem, Coelli, and Rao (2012). The remained group of studies provided a mixed result on the impact of microfinance on welfare, which microfinance have positive effect to a group of participants, while its retrogressive for others (Coleman, 2006). In Vietnam most of studies used an observational approach, lead to limited reliability. Few studies applied econometric model to examine the impact of microfinance, such as Quach et al., (2007) and Nghiem, Coelli, and Rao (2007).

The objective of this paper is to examine whether and to what extent formal microfinance programs have helped to increase household economic welfare in rural Vietnam.

\section{MATERIALS AND METHODS}

\section{Study site and data collection}

In July and August 2015, a survey was conducted of 257 households in Phu Tho province through face-toface structured questionnaires. Phu Tho is one of the poorest areas, located in northern of Vietnam. Until 2014 , the poor and near poor household has accounted for $20.9 \%$ of the total province's household. The prov- 
ince covers an area of 3528.1 square kilometers (account for 1.2 percent of the total country area and placed $38 / 64$ of provinces and cities nationwide), of which $54.8 \%$ is used for agriculture and forestry. The province has population of 1,488,049 people in 2015 (GSO). With mountain, midland and delta topography, the province has inclusive economic activities such as cultivation, livestock and aquaculture rising, fruit planting, forestry, natural mineral resources exploitation, etc. Especially, planting and cultivating the wax tree, which used to produce lacquer from its resin, is one of their important activities. However, it's difficult for financial situations because of the geographic intensive division. Microfinance development is important with the people living.

In this province, we purposively selected two target districts namely Cam Khe and Thanh Son because they have the appearance of all types of formal microfinance institutions. These districts have similar demographic and stay near each other. Households who have borrowed from only one of the microfinance providers and who haven't borrowed from any microfinance providers were selected randomly from a list of providers and districts. From survey respond, 47 households were collected for non-client of formal microfinance while 210 households were collected for client. Among them, 49 households participated in Vietnam Bank for Social Policy- a state-own bank aiming to support the poor, with the average loan of 24.5 million VND at 8.3\%; 94 households participated in non-governmental microfinance organization TYM with the average loan of 19.3 million VND at 12\%; 63 households participated in the Vietnam Bank for Agriculture and Rural Development- a commercial bank, with the average loan of 82 million VND at $12.5 \%$; and 4 households are belonging to People credit fund. Thus, the analysis is concentrated on three main providers.

\section{Empirical model}

To examine the impact of microfinance on household welfare, we adapted a welfare function model used by Pitt and Khandker (1988). The household welfare $\mathrm{Y}_{\mathrm{ij}}$ explained as $Y_{i j}=\alpha+\beta_{Y} X_{i j}+\gamma_{Y} V_{i j}+\delta C_{i j}+\varepsilon_{i j}{ }^{Y}$; where $\mathrm{C}_{\mathrm{ij}}$ denotes household borrowings in three main formal microfinance providers; $\mathrm{X}_{\mathrm{ij}}$ denotes observed household characteristics. $\mathrm{V}_{\mathrm{ij}}$ is the village characteristic. $\beta, \gamma$ and $\delta$ are unknown parameters and $\varepsilon^{y}$ is the error term. Because the placement of microfinance providers is not random due to their preference in best potential borrowers and area, measuring the borrowing in microfinance programs might face selection bias Quach et al., (2007). Then credit might be correlated with unobservable characteristics, being an endogenous variable.

The credit $\mathrm{C}_{\mathrm{ij}}$ depends on $C_{i j}=\alpha+\beta_{C} X_{i j}+\gamma_{C} V_{i j}+\pi Z_{i j}+\varepsilon_{i j}{ }^{C}$; where $Z_{\mathrm{ij}}$ denotes a set of household or village characteristics which are different from the $\mathrm{X}$ and $\mathrm{V}$ in that they affect $\mathrm{C}_{\mathrm{ij}}$ (instrumental variables). Based on the demand theory, the price of a loan is a good predictor for credit demand. The price of a microloan is loan interest rate and the rate of required deposit for this loan because microfinance often required an amount of deposit. For each provider, if households sign borrowing contract at the same year and under same loan term, their interest rate will be the same. Furthermore, Nghiem et al., (2012) emphases the relationship between duration in microfinance and amount of loans received when examine microfinance impact. Duration in credit activity supports household to take credit when the household is more familiar with applying and managing the capital. Because the households are clients from three different providers, duration or years of experience in microfinance might be better to measuring credit. The interest rate and duration are different, based on different by provider, year of signing borrowing contract and years of loan (loan term) for each individual; therefore, these variables are different over household. Hence, this paper uses three variable including interest of micro loan, interest of required deposit and duration in microfinance as instrumental variables. In this paper, we adopt the two stages least square (2SLS) to resolve the problems. Because the credit amount $\mathrm{C}_{\mathrm{ij}}$ is censored data, including "zero" value for non-clients, we uses Tobit model for the first regression (Khandker and Faruquee, 2003; Quach et al., 2007). The predicted, rather than actual, amount of credit obtained from the first-stage regression is inserted in the second stage; this stage helps correct for selfselection bias.

When investigate the contribution of microfinance to rural household welfare, it's important to clarify the purpose of lending. Data indicate that among 210 households taken microcredit, 155 households used credit for their small business while 55 households used credit for consumption, medical treatment, children education and debt repayment. However, it's difficult to separate credit for each purpose, because households flexibly use capital when needed, regardless the lending purpose. Also, they may finance loan for many purposes at the same time. Therefore, this study doesn't take the using of loan based on their original purpose into consideration.

Table 1 describes variables using for the 2SLS and their general statistics. Household welfare is measured as per capita income, expenditure and value of non-land assets regarding Khandker and Faruqee (2003) and Rahman, Luo, and Minjuan, (2015). A typical household head in the study area is around 43 years old, mostly work as a farmer, have their own house and farm. An average distance from a household to the nearest township is $8.32 \mathrm{~km}$.

\section{RESULTS AND DISCUSSION}

\section{Factors influencing participation in formal micro- finance}

Table 2 presents the determinant of credit in microfinance programs. The results indicate household heads that are male, owned business; having experience and training in agriculture are likely to access microfinance. In tradition of Vietnam, male often are household decision makers. In addition, household head that owns business is expected to require more credit for business operation in compare with agriculture activity. 
Table 1. List of variables used in 2SLS model and descriptive statistics

\begin{tabular}{llrr}
\hline \multicolumn{1}{c}{ Variable } & \multicolumn{1}{c}{ Description } & Mean & S.D \\
\hline incomepc & Total per capita income in 2014 (Million VND) & 25.40 & 16.94 \\
expensepc & Total per capita expenditure in 2014 (Million VND) & 12.49 & 8.38 \\
assetpc & Total per capita value of non-land asset (Million VND) & 28.87 & 26.62 \\
credit & Amount of loan borrowed from MF provider in 2014 (Mill VND) & 33.86 & 41.98 \\
age & Age of household head (Years) & 43.07 & 11.06 \\
gender & Gender of household head: 1=male, 0=female (Dummy) & 0.51 & 0.50 \\
job & Main occupation of household head: 1=farmer, 2=own business, 3=casual & 1.77 & 1.09 \\
distance & labor, 4=employee (Category) & 8.32 & 4.37 \\
depend & Distance from the village to nearest township (Km) & 0.69 & 0.57 \\
hs_size & Dependence ratio of HH (equal dependence/HH labor) & 96.74 & 76.84 \\
farm_size & Total house size (0 if HH doesn't have house) (m2) & $1,001.33$ & $1,981.48$ \\
machine & 1=if household has machine used for production, 0=none (Dummy) & 0.22 & 0.41 \\
expr_agri & Years of HH head's experience in farming (Years) & 14.72 & 11.06 \\
expr_bus & Years of HH head's experience in business (Years) & 2.76 & 5.25 \\
train_agr & 1=if HH head has training about farming, 0=none (Dummy) & 0.28 & 0.45 \\
train_bus & 1=if HH head has training about business, 0=none (Dummy) & 0.11 & 0.31 \\
expr_cre & Cumulative duration of micro loans (Years of HH head's experience in MF) & 4.36 & 3.69 \\
int_loan & Average interest rate of the current micro loan (\%) & 9.18 & 4.65 \\
int_saving & Average interest rate of the required deposit from micro loan (\%) & 1.37 \\
\hline
\end{tabular}

Note: VND: Vietnam Dong; 1USD = 22.537 VND (2015/08); "Average interest rate" is the average interest rate of all individual household's loans or savings, which was calculated based on the weight average of interest rate and duration (loan term); Source: Self survey 2015;

Table 2. Determinants of microcredit (First stage Tobit regression)

\begin{tabular}{|c|c|c|c|}
\hline $\begin{array}{l}\text { Independent } \\
\text { variable }\end{array}$ & $\begin{array}{c}\text { Coefficient } \\
\text { (t-sta) }\end{array}$ & $\begin{array}{c}\text { Independent } \\
\text { variable }\end{array}$ & $\begin{array}{l}\text { Coefficient } \\
\text { (t-sta) }\end{array}$ \\
\hline age & $0.19(0.79)$ & farm_size & $5 \mathrm{E}-04(0.57)$ \\
\hline gender & $21.51(2.92 * * *)$ & machine & $0.22(0.04)$ \\
\hline job & & expr_agri & $0.48\left(1.68^{*}\right)$ \\
\hline business & $28.49\left(3.35^{* * *}\right)$ & expr_bus & $-0.3(-0.46)$ \\
\hline casual labor & $-8.29(-1.15)$ & train_agr & $28.8\left(6.07^{* * *}\right)$ \\
\hline employee & $5.13(0.6)$ & train_bus & $10.78(1.58)$ \\
\hline lndistance & $4.01(0.63)$ & expr_cre & $1.14\left(1.83^{*}\right)$ \\
\hline depend & $-3.13(-0.82)$ & int_loan & $11.35\left(13.1^{* * *}\right)$ \\
\hline hs_size & $3 \mathrm{E}-03(0.09)$ & int_saving & $-14.56(-5.22 * * *)$ \\
\hline _cons & $-101.44(-4.57 * * *)$ & Pseudo $R^{2}$ & 0.132 \\
\hline LL ratio $\mathrm{Chi}^{2}(1$ & 299.57 & No of obs & 253 \\
\hline
\end{tabular}

Note: $\mathrm{N}=253 ; * * *, * * *$ indicate that the coefficients are significant at the $1 \%, 5 \%$, and $10 \%$ level, respectively.

All instrument variables including year of experiences in credit activity (duration), interest rate of micro loan and required deposit are significant. It's expected that households with more credit experience are easier to renew the micro loan as well as more amount demanding. However, the sign of coefficient in credit and required savings interest rate imply that household might prefer higher interest rate for bigger credit. This might be because in Vietnam formal microfinance market, provider, which requires higher interest rate, often supplies a bigger amount of loans. This finding support the true reality that demand for micro credit is much larger than the providing. According to Malcom Harper (1998), demand for microloans is highly inelastic for poor borrowers. Our finding has contradicted with the previous studies about interest rate; therefore it requires a future research about the provision of microfinance in rural area and household access to rural credit.

\section{Impact of microfinance on household welfare}

Before conducting the second stage regression, we have some test for endogeneity, for the strength and over-identifying restrictions of instruments. Then the Durbin-Wu-Hausman test determined which model is suitable by get the residual from the first equation; estimate its predicted value then test the significance and include in the second stage regression. According to table 3, all outcomes are systematics different between the two models. Then 2SLS are more appropriate than OLS. The Sargan test for over-identify restriction reject null hypothesis that all instruments are uncorrelated with error term from equations of per capita expenditure and asset outcomes at $5 \%$, but could not reject that of per capita income outcomes. However, if we take out one of the instruments, the credit function might be misleading. Moreover, F-statistics F $(3,235)$ equal 72.576 
reject the null hypothesis that instruments are weak. Then in this study, we still keep all instruments variables.

Table 4 shows the determinants of household welfare in terms economics indicators. It can be seen that microfinance has a significant positive association with per capita income, expenditure and non-land asset of the household. With 1\% increase in formal borrowings is associated with $0.002 \%, 0.004 \%$ and $0.003 \%$ increase in per capita income, expenditure and asset, respectively. This is in line with previous findings that providing microfinance may improve household economic welfares and reduce poverty (Khandker and Faruqee, 2003, and Quach et al., 2007). Khandker and Faruqee (2003) argued that $1 \%$ increase in borrowing increases annual consumption by $0.004 \%$, and increases non-land assets by $0.005 \%$ in Bangladesh. Quach et al. (2007) implied that $1 \%$ increase in credit increases per capita expenditure by $0.058 \%$ in Vietnam. Therefore, microfinance can improve household welfare in the study area. However, these impacts are relatively small. In this case, the benefit of delivery credit might be lower than the cost, raising question about the subsidizing cheap credit to reduce

Table 3. DTest of endogeneity (the Durbin-Wu-Hausman test)

\begin{tabular}{lll}
\hline Household welfare & F (1,236) & $\mathrm{P}>\mathrm{F}$ \\
\hline incomepc (log) & 5.057 & 0.025 \\
expensepc (log) & 4.621 & 0.033 \\
assetpc (log) & 3.3674 & 0.057 \\
\hline
\end{tabular}

poverty causing low marginal impact. Thus authorities should coordinate microfinance supply with other development such as job creation. Also, this result suggests that expenditure smoothing maybe a stronger impact of microfinance, compare to income generating.

Table 5 illustrates impact of microfinance on household welfare across different income level. The sample size was divided into two group based on international poverty line (\$1.9PPP/day/person). Poor household group was classified if household has per capita income lower than 15.5 million VND. Regarding table 5, microfinance is positively and significantly related to per capita expenditure and asset of the poor group, meanwhile it positively and significantly related to per capita income and expenditure the better-off group. These results imply while better-off households access credit can increase income and expenditure, poor households tend to use microcredit for smoothing for their basic needs. With 1\% increase in borrowing, expenditure and asset of poor household is likely to increase by $0.004 \%$ and $0.006 \%$, while better-off households are likely to increase income and expenditure by $0.003 \%$ and $0.002 \%$. Thus microfinance programs help yield better outcome for better-off household in term of income, while poor household acquire more expenditure and asset when have microcredit.

\section{CONCLUSION}

The results indicate that microfinance programs have positively and significantly related to the household

Table 4. Impact of Microfinance on household welfare

\begin{tabular}{|c|c|c|c|}
\hline & $\begin{array}{l}\text { Per capita income (log) } \\
\text { Coefficient (t-sta) }\end{array}$ & $\begin{array}{l}\text { Per capita expense (log) } \\
\text { Coefficient (t-sta) }\end{array}$ & $\begin{array}{l}\text { Per capita asset (log) } \\
\text { Coefficient (t-sta) }\end{array}$ \\
\hline credit & $0.002\left(1.69^{*}\right)$ & $0.004\left(3.29^{* * *}\right)$ & $0.003\left(1.76^{*}\right)$ \\
\hline age & $-0.001(-0.39)$ & $-0.003(-0.74)$ & $0.004(0.8)$ \\
\hline gender & $-0.261\left(-2.79^{* * *}\right)$ & $-0.108(-1.21)$ & $-0.176(-1.33)$ \\
\hline own business & $0.013(0.08)$ & $0.065(0.44)$ & $0.349(1.6)$ \\
\hline casual labor & $0.042(0.36)$ & $-0.052(-0.47)$ & $0.152(0.92)$ \\
\hline employee & $0.568\left(4.78^{* * *}\right)$ & $0.517\left(4.56^{* * *}\right)$ & $0.33(1.96 * *)$ \\
\hline lndistance & $-0.105(-1.41)$ & $-0.051(-0.71)$ & $0.125(1.19)$ \\
\hline depend & $-0.234(-3.75 * * *)$ & $-0.247\left(-4.13^{* * *}\right)$ & $-0.146\left(-0.166^{*}\right)$ \\
\hline hs_size & $-0.001(-1.44)$ & $-3 \mathrm{E}-04(-0.61)$ & $1 \mathrm{E}-04(0.15)$ \\
\hline farm_size & $3 \mathrm{E}-05\left(1.85^{*}\right)$ & $-7 \mathrm{E}-06(-0.4)$ & $6 \mathrm{E}-05\left(2.3^{* *}\right)$ \\
\hline machine & $0.15\left(1.67^{*}\right)$ & $0.065(0.76)$ & $0.206\left(1.63^{*}\right)$ \\
\hline expr_agri & $-0.014\left(-3.11^{* * *}\right)$ & $-0.008\left(-1.84^{*}\right)$ & $-0.017(-2.74 * * *)$ \\
\hline expr_bus & $0.023(2.23 * *)$ & $0.012(1.26)$ & $0.005(0.31)$ \\
\hline train_agr & $-0.067(-0.73)$ & $-0.280\left(-3.21^{* * *}\right)$ & $0.399\left(3.1^{* * *}\right)$ \\
\hline train_bus & $0.157(1.31)$ & $-0.021(-0.19)$ & $0.279\left(1.65^{*}\right)$ \\
\hline _cons & $3.577(17.59 * * *)$ & $2.757\left(14.19^{* * *}\right)$ & $2.56\left(8.91^{* * *}\right)$ \\
\hline $\mathrm{R} 2$ & 0.409 & 0.312 & 0.22 \\
\hline Wald Chi2 (15) & 183.27 & 124.52 & 78.3 \\
\hline
\end{tabular}

Note: $\mathrm{N}=253 ; * * *, * * *$ indicate that the coefficients are significant at the $1 \%, 5 \%$, and $10 \%$ level, respectively 
Table 5. Influence of credit on household welfare across sub-sample

\begin{tabular}{cccc}
\hline $\begin{array}{c}\text { Dependent } \\
\text { variables } \\
\text { (logarithm) }\end{array}$ & $\begin{array}{c}\text { The whole } \\
\text { sample } \\
\text { Coefficient }\end{array}$ & $\begin{array}{c}\text { Poor } \\
\text { households } \\
\text { Coefficient }\end{array}$ & $\begin{array}{c}\text { Better-off } \\
\text { households } \\
\text { Coefficient }\end{array}$ \\
\hline incomepc & $0.002\left(1.69^{*}\right)^{\mathrm{a}}$ & $2 \mathrm{E}-04(0.17)$ & $0.003\left(2.63^{* * *}\right)^{\mathrm{a}}$ \\
expensepc & $0.004\left(3.29^{* * *}\right)^{\mathrm{a}}$ & $0.004\left(2.15^{* *}\right)^{\mathrm{a}}$ & $0.002\left(2.33^{* *}\right)^{\mathrm{b}}$ \\
Assetpc & $0.003\left(1.76^{*}\right)^{\mathrm{a}}$ & $0.006\left(1.7^{*}\right)^{\mathrm{a}}$ & $0.002(1.14)$ \\
\hline No of obs & 253 & 78 & 175 \\
\hline
\end{tabular}

Note: $\mathrm{N}=253, * * *, * * *$ indicate that the coefficients are significant at the $1 \%, 5 \%$, and $10 \%$

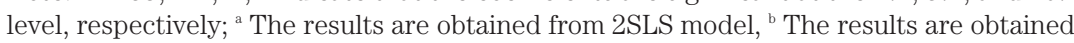
from OLS model

economic welfare in rural Vietnam in term of per capita income, expenditure and non-land asset of the household. Although the effect is small, microfinance has helped the better-off groups to increase their income and expenditure, while the poor groups increase their expenditure and acquire more assets, implying that the credit is distributed to other purpose besides income generating. Better off household may easier to concentrate the credit to create more income, while poor household may spend more for smoothing the livings when they receive credit. However, these impacts are very small, suggesting a further study about the cost-effective of the microfinance programs. Microfinance provider with cheap credit subsidized might cause low marginal impact because of high cost operation. In addition, the study supports prior findings about the better impact of microfinance on better-off households than the poor in term of income generating. The results have implications for development practitioners and policy makers in Vietnam. Microfinance can be an instrument for poverty alleviation. However, they need to focus on improving the efficiency of providing microfinance, especially for the poor.

\section{REFERENCES}

Coleman, B. E 2006 Microfinance in northeast Thailand: Who benefits and how much?, World Development, 34 (9): 1612-1638

Khandker, S. R. and Faruquee, R. R 2003 The impact of farm credit in Pakistan, Agriculture Economics, 28: 197-213

Nghiem, H. S., Coelli, T. and Rao, P. 2007 The Welfare Effects of Microfinance in Vietnam: Empirical Results From a QuasiExperiment Survey, Annual Conference of the Australian Agriculture and Resources Economics Society, Queenstown (New Zealand) , pp. 1-39

Nghiem, H. S., Coelli, T. and Rao, P. 2012 Assessing the Welfare Effects of Microfinance in Vietnam: Empirical Results from a Quasi-Experimental Survey, J. Development Studies, 48: 619632

Nguyen, K. A, Ngo, V. T, Le, T. T and Nguyen, T. T. M 2011 Microfinance Versus Poverty Reduction in Vietnam Diagnostic Test and Comparision, Hanoi, Thong Ke.

Pitt, M. M. and Khandker, S. R 1998 The Impact of Group-Based Credit Programs on Poor Households in Bangladesh: Does the Gender of Participants Matter?, J. Political Economy, 106 (5): 958.

Quach, H., Mullineux, A and Murinde 2007 Access to Credit and Household Poverty Reduction in Rural Vietnam: A cross-sectional Study, Research in Accounting in Emerging Economies, 7: 279-307

Rahman, M. W, Luo, J and Minjuan, Z 2015 Welfare impact of microcredit programs: An empirical investigation in the statedestination poor countries of Shaanxi, China. 